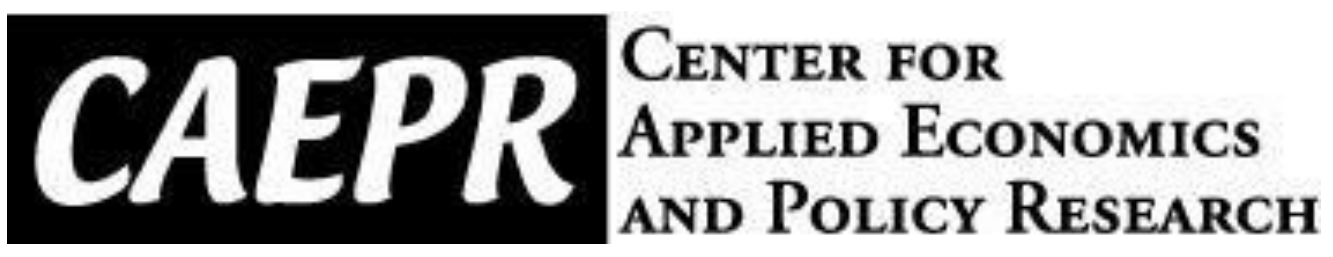

\author{
CAEPR Working \\ Paper \\ \#2013-01 \\ Recent Issues in
Emerging-Economies
Macroeconomics
}

Tack Yun

Seoul National

University

October 2012

The Center for Applied Economics and Policy Research resides in the Department of Economics at Indiana University Bloomington. CAEPR can be found on the Internet at: http://www.indiana.edu/ caepr. CAEPR can be reached via email at caepr@indiana.edu or via phone at 812-855-4050.

(C2013 by Tack Yun All rights reserved. Short sections of text, not to exceed two paragraphs, may be quoted without explicit permission provided that full credit, including $\odot$ notice, is given to the source. 


\title{
Recent Issues in Emerging-Economies Macroeconomics
}

\author{
Prepared by Tack Yun \\ Department of Economics \\ Seoul National University \\ This Draft: October, 2012
}

\begin{abstract}
In this paper, we summarize the recent advancement of emerging-economies macroeconomics. We begin with stylized facts and models of real business-cycles for emerging-market countries and then move onto the discussion of various issues associated with overborrowings and sovereign debts. The common feature of these models is that their analysis is mainly focused on the framework of RBC models for small open economies combined with financial frictions. We also discuss nominal features of emerging economies that are associated with the behavior of nominal exchange rate and foreign reserves observed during the recent global financial crisis, as well as the practice and impact of conventional and unconventional monetary policy measures.

We also present some extensions of existing emerging-economies models that allow for the significant role of conventional monetary and fiscal policies. Our results can be summarized as follows. First, the canonical specification of recent models with pecuniary externalities is modified to allow for channels through which conventional monetary and fiscal policies can affect the degree of pecuniary externalities. Second, we attempt to explain the behavior of nominal exchange rate "going up elevators and coming down stairs" shown in emerging economies during periods of zero lower bounds on the short-term nominal interest rate. Third, we modify a prototypical model of sovereign debt to show the negative correlation between the maturity of foreign debt and the accumulation of foreign reserves when the level of foreign debt is substantially high.
\end{abstract}

JEL classification: E31; E32; E41

Keywords: Business Cycles; Emerging-Market Economies; Overborrowings; Exchange Rate

E-mail address: tackyun@snu.ac.kr.

This monograph is prepared for a special edition of International Economic Journal and supported by the research fund of Social Science Korea program (Search for a New Framework in the Analysis of the Korean Economy: Based on a New Perspective about Emerging Market Countries). I appreciate valuable comments from participants at the annual conference of International Economic Journal held in June 2012. All errors are my own. 


\section{Contents}

1. Introduction: Initiation of Emerging-Economies Macroeconomics

- Emphasis on real macroeconomic models: simple model framework and close connection with RBC models

- Role of DSGE models for the policy analysis of macroprudential measures

2. Stylized facts and models of real business-cycles for emerging-market countries

- Sources of emerging-market business cycles

- Role of financial frictions

3. Overborrowings and models of sovereign debts

- Overborrowings

- Pecuniary externalities and macroprudential policies in emerging-market economies

4. Development of policy models

- Recent financial crisis: conventional and unconventional monetary policy measures in emerging economies

- Behavior of nominal exchange rate during recent financial crises in emerging economies

- Predictions of New Keynesian models about the behavior of nominal exchange rates during periods of zero lower bounds on nominal short policy rates

5. New directions for emerging-market macro models

- Regional and economic difference in emerging economies

- Financial stability and monetary policy in emerging economies 


\section{Introduction: Initiation of Emerging-Economies Macroeco- nomics}

The macroeconomics for emerging-economies has addressed academic research and practical policy issues that are associated with emerging economies. In particular, its emphasis on key real macroeconomic variables within simple frameworks originates from its initial academic research questions. In other words, most emerging-economies macro models draw on the framework of RBC models. The main reason behind this feature is that many researchers in this field have addressed the research issue of whether or not the canonical RBC model of small open-economies such as Mendoza (1991) is reconciled with excessive consumption volatilities (relative to output volatilities) and countercyclical movements of net export observed in emerging economies. In fact, this research issue is the identification of real aggregate shocks that drive aggregate fluctuations of emerging economies within the RBC framework of small open economies.

The result of Aguiar and Gopinath (2007) is in favor of the argument that the canonical RBC model of small open-economies such as Mendoza (1991) is reconciled with emerging-market business cycles if one allows for substantial fluctuations of the permanent component of the aggregate total factor productivity. However, on top of conventional technology shocks in prototypical RBC models, another plausible candidate as a major driving force for emerging-market business cycles is the interest rate shock, as shown in Uribe and Yue (2006). In this vein, Garcia-Cicco, Pancrazi, and Uribe (2010) demonstrate that, when one wants to match relatively long periods of emerging-market data, their data are in favor of a small-open RBC model with country premium shocks whose output effect is amplified by financial frictions that makes the country spread dependent upon the level of sovereign debt.

From a broader perspective that reflects practical policy questions, Frankel (2011) also summarizes a set of reasons why it is desirable to have different models for emerging economies:

- Developing countries tend to have less developed institutions (almost by definition), and specifically to have lower central bank credibility, than industrialized countries.

- Goods markets of small developing countries are often more exposed to international influences than those of Europe or Japan.

- Developing countries tend to be subject to more volatile aggregate fluctuations than rich countries.

- Another structural difference is the greater incidence of default risk.

- Additional imperfections in financial markets can sometimes be traced to underdeveloped 
institutions, such as poor protection of property rights, bank loans made under administrative guidance or connected lending, and even government corruption.

The recent emphasis on various issues of macroprudential policies in the macroeconomics of emerging-economies is closely associated with the fact that emerging countries have been more frequently hit by economic crises that are followed by severe macroeconomic recessions. It has been remarked in both academic and practical policy circles that emerging countries have had much greater experience than advanced countries in the use of macroprudential policy instruments, as a way of preventing or avoiding potential adverse consequences of economic crises.

The recent emerging-economies literature reflects explicitly or implicitly the view that the comprehensive and systemic analysis of important policy issues requires the persistent development of DSGE models that are well suited to the analysis of emerging economies. For example, the key lesson of the recent global financial crisis is the importance of monitoring systemic connections among credit-market participants and guiding their behaviors especially at good times in suffering from less severe and less frequent financial crises. In this vein, the design of macro-prudential policy requires the development of models that capture the macro consequences of financial crises well by allowing for well-approximated connections between macro-prudential policy instruments and the actions of credit market participants, as noted in Bianchi, Boz, and Mendoza (2012). But developing such models is a challenging task because of rapid developments of financial sector.

\section{Models of Business-Cycles for Emerging-Market Countries}

The key characteristics of aggregate fluctuations in emerging-market countries are excessive consumption volatilities (relative to output volatilities) and countercyclical movements of net export. In particular, the observation that these two stylized facts are not easily reconciled with predictions of canonical RBC models of small open economies can be emphasized as the main reason for a new theoretic framework to explain emerging-market business cycles.

The identification of sources of emerging-market business cycles has been an important topic in the literature. The initial debate (among researchers) in this vein is the predominance of the permanent component of trend technology shocks in emerging-market business cycles as discussed in Durdu (2012). The well-known conclusion of Aguiar and Gopinath (2007) is that the permanent component of total factor productivity plays a substantial role in the aggregate fluctuations in emerging-market countries. ${ }^{1}$ However, Garcia-Cicco, Pancrazi, and Uribe (2010) demonstrate that, when one wants to match relatively long periods of emerging-market data, their data are in favor of

\footnotetext{
${ }^{1}$ For example, in their analysis, the total factor productivity at period $t$ can be decomposed into a stationary component and a permanent component: $T F P_{t}=A_{t} X_{t}^{1-\alpha}$ where $A_{t}$ represents the stationary component at period $t$ and $X_{t}$ is the permanent component.
} 
Table 1: Standard Deviations of Key Economic Variables

\begin{tabular}{rlllllll}
\hline & $\sigma(Y)$ & $\sigma(C)$ & $\sigma(I)$ & $\sigma(R N Y)$ & $\sigma(T O T)$ & $\frac{\sigma(C)}{\sigma(Y)}$ & $\frac{\sigma(I)}{\sigma(Y)}$ \\
\hline Selected Developed Countries & & & & & & & \\
Canada & 0.9 & 0.8 & 0.9 & 0.4 & 0.7 & 0.88 & 0.99 \\
France & 1.3 & 1.3 & 2.5 & 0.1 & 0.8 & 0.96 & 1.85 \\
Japan & 3.0 & 3.0 & 5.6 & 0.1 & 2.7 & 1.00 & 1.85 \\
USA & 0.4 & 0.4 & 1.6 & 0.1 & 1.2 & 0.99 & 3.43 \\
Emerging Latin Countries & & & & & & & \\
Argentina & 1.2 & 0.9 & 3.2 & 0.3 & 3.9 & 0.77 & 2.62 \\
Brazil & 2.5 & 2.5 & 3.6 & 0.2 & 1.5 & 0.99 & 1.41 \\
Chile & 1.5 & 1.9 & 4.0 & 0.6 & 4.0 & 1.31 & 2.67 \\
Mexico & 1.7 & 1.3 & 2.6 & 0.2 & 1.7 & 0.78 & 1.50 \\
Peru & 2.0 & 2.9 & 2.9 & 0.2 & 2.2 & 1.41 & 1.43 \\
Venezuela & 2.2 & 2.6 & 4.3 & 1.5 & 5.4 & 1.16 & 1.93 \\
& & & & & & & \\
Emerging Asia & & & & & & \\
Taipei, China & 1.9 & 2.1 & 4.7 & 0.7 & 1.5 & 1.10 & 2.49 \\
Indonesia & 1.8 & 1.7 & 4.7 & 0.8 & 8.7 & 0.92 & 2.58 \\
Korea & 1.6 & 1.4 & 4.6 & 0.8 & 1.5 & 0.89 & 2.81 \\
Malaysia & 1.2 & 0.9 & 4.1 & 0.4 & 1.3 & 0.77 & 3.34 \\
Philippines & 1.5 & 0.9 & 3.0 & 0.6 & 1.4 & 0.58 & 1.88 \\
Thailand & 2.1 & 1.8 & 4.7 & 0.6 & 2.5 & 0.71 & 2.19 \\
China & 1.8 & 1.6 & 1.6 & 0.3 & 2.9 & 0.89 & 0.89 \\
\hline
\end{tabular}

Note: The numbers reported in this table are taken from Jung, Kim, Yang and Yun (2012). 
a small-open RBC model with country premium shocks whose output effect is amplified by financial frictions that makes the country spread dependent upon the level of sovereign debt. Hence, their model specification requires the endogenous determination of the country spread, which is not emphasized in the model of Aguiar and Gopinath.

Another dimension in the identification of sources of emerging-market business cycles is the importance of interest rate shocks in driving stylized facts of emerging-market countries on top of trend growth shocks. This line of research begins with the observation that the cost of borrowing faced by emerging economies fluctuates over time and periods of high interest rates are associated with their economic downturns. For example, Uribe and Yue (2005) demonstrate:

- US interest rate shocks explain about 20 percent of movements in aggregate activity in emerging economies.

- Country spread shocks explain about 12 percent of business cycles in emerging economies.

- In response to an increase in US interest rates, country spreads first fall and then display a large and delayed overshooting.

- US-interest-rate shocks affect domestic variables mostly through their effects on country spreads.

- The feedback from emerging-market fundamentals to country spreads significantly exacerbates business-cycle fluctuations.

Mendoza and Yue (2010) argues that it is necessary to incorporate a close connection between business-cycle models and sovereign-default models into models of business cycles if one is to explain stylized facts of emerging-market countries. Specifically, their argument relies on the following three key empirical regularities that characterize the relation between sovereign debt and aggregate fluctuations in emerging economies:

- Output displays $V$-shaped dynamics around defaults.

- Interest rates on sovereign debt and GDP are negatively correlated.

- External debt as a shore of GDP is high on average, and higher when countries default.

An implication of these facts is that it is not easy to reflect the true role of sovereign default for sharp declines in real output when output costs of sovereign defaults are exogenous, and a country's default premium is high when it defaults. Hence, their research question is to develop a model that solves the crucial disconnect between business cycle models that treat default risk as an exogenous 
Table 2: Comovements of Key Economic Variables

\begin{tabular}{rccccc}
\hline & $\rho(Y, C)$ & $\rho(Y, I)$ & $\rho(Y, R N Y)$ & $\rho(Y, T O T)$ & $\rho(T O T, R N Y)$ \\
\hline Selected Developed Countries & & & & & -0.86 \\
Canada & 0.84 & 0.53 & 0.28 & -0.11 & -0.21 \\
France & 0.98 & 0.88 & 0.11 & 0.14 & -0.91 \\
Japan & 0.98 & 0.98 & -0.47 & 0.42 & -0.34 \\
USA & 0.94 & 0.73 & -0.16 & 0.33 & \\
Emerging Latin Countries & & & & & -0.21 \\
Argentina & 0.67 & 0.96 & -0.23 & 0.20 & -0.71 \\
Brazil & 0.99 & 0.91 & -0.07 & 0.05 & -0.87 \\
Chile & 0.88 & 0.78 & -0.40 & 0.59 & -0.49 \\
Mexico & 0.97 & 0.84 & 0.28 & 0.09 & -0.22 \\
Peru & 0.92 & 0.27 & -0.24 & 0.29 & -0.89 \\
Venezuela & 0.92 & 0.58 & 0.21 & -0.45 & -0.74 \\
Emerging Asia & & & & & -0.63 \\
Taipei, China & 0.95 & 0.91 & -0.57 & 0.27 & -0.89 \\
Indonesia & 0.81 & 0.88 & -0.52 & 0.68 & 0.02 \\
Korea & 0.96 & 0.84 & -0.69 & 0.74 & -0.77 \\
Malaysia & 0.49 & 0.58 & 0.09 & 0.02 & -0.89 \\
Philippines & 0.89 & 0.72 & 0.54 & -0.61 & -0.87 \\
Thailand & 0.98 & 0.68 & -0.04 & -0.43 & -0.03 \\
China & 0.98 & 0.98 & 0.60 & & \\
\hline
\end{tabular}

Note: The numbers reported in this table are taken from Jung, Kim, Yang and Yun (2012).

interest rate on working capital, and sovereign default models that treat output fluctuations as an exogenous process with ad-hoc default costs.

More specifically, Mendoza and Yue (2011) show that the incorporation of counter-cyclical interest rate shocks into emerging-market models of business cycles helps match emerging-market data when they are combined with working capital constraints. In particular, this feature helps match countercyclical movements of trade balance that are measured by the correlation of real output with net exports. In addition, the key mechanism behind this result is that an increase in the interest rate leads to a rise in the tightness of working capital constraint, thus reducing firms' demands for production inputs, while the resulting decrease in the real output exacerbates the trade balance.

In their model, we note that a tighter working capital constraint leads to a more counter-cyclical movements of trade balance. It is thus necessary to heighten the tightness of this constraint if there are counter-cyclical movements of trade balance in the actual data. Hence, at issue is whether or not their model can successfully replicate observed counter-cyclical movements of trade balance under a plausible calibration for the tightness of working capital constraint. 


\section{Overborrowings}

The financial integration of emerging market economies into international financial markets has led them to experience far more volatile fluctuations in goods and financial markets at the same time. The key ingredient of this phenomena is the boom-bust cycles in foreign capital flows. For example, emerging-market countries experience strong capital inflows during good times and often create the issue of overborrowings, while the capital flows reverse during bad times and often trigger systemic financial crises. Hence, overborrowings may be one of the key sources to magnify business cycles of emerging-market countries. The issue of overborrowings creates the need for prudential controls on capital flows in emerging economies from a practical policy perspective and even from a welfare theoretic perspective.

In this section, we are focused on the pecuniary externalities in the international capital market as the key mechanism to create the issue of overborrowings. In recent works of Bianchi (2011) and Korineck (2011), the presence of financial frictions that leads to collateral constraints for households is the key ingredient to generate pecuniary externalities. In particular, collateral constraints are exogenous to individual households but endogenous to the economy as a whole. Specifically, a specific form of the collateral constraint for an individual household can be written as follows:

$$
b_{1} \leq \kappa\left(y_{1}^{T}+p_{1}^{N} y_{1}^{N}\right)
$$

where $b_{1}$ is the real amount of debt, $y_{1}^{T}$ is the real output of tradable goods, $y_{1}^{N}$ is the real output of non-tradable output, and $p_{1}^{N}$ is the relative price of non-tradable goods. ${ }^{2}$

In this equation, $y_{1}^{T}+p_{1}^{N} y_{1}^{N}$ can be interpreted as the international collateral of domestic borrowers. Moreover, a decline in the relative price of non-tradable goods $p_{1}^{N}$ reduces the international collateral, thus lowering the borrowing capacity of domestic consumers. Hence, this constraint captures the notion of balance-sheet effects. A question is whether non-tradable income or assets can be an effective part of collateral for international borrowing and lending relationships between private agents. This question may be legitimate because international lenders cannot export non-tradable goods. However, Korineck (2011) argues that international lenders can seize them in the domestic court system and sell them against tradable goods at the prevailing market price $p_{1}^{N}$.

Moreover, pecuniary externalities can arise because the equilibrium relative price of non-tradable goods is a function of tradable consumption good: $p_{1}^{N}=p\left(c_{1}^{T} / y_{1}^{N}\right)$ where $c_{1}^{T}$ denotes the tradable

\footnotetext{
${ }^{2}$ Korineck (2011) proposes a potential microfoundation for this constraint as follows. Assume that consumers may threaten default after taking on their debts and that they can renegotiate their debts at the end of period 1 . If they default, international lenders can seize at most a fraction $\kappa$ of the income of consumers in that period, convert all nontradable goods into tradable goods at the prevailing market price $p_{1}^{N}$, and repatriate what they receive. If consumers have all the bargaining power, they could renegotiate their debt down to the level indicated by the constraint, and lenders would not be willing to lend more than this level.
} 
Table 3: Decentralized Equilibrium versus Planner's Optimality Conditions

\begin{tabular}{ll}
\hline \hline$\lambda_{t}=M U_{t}$ & $\lambda_{t}^{s p}=M U_{t}+\mu_{t}^{s p} \Phi_{t}$ \\
$p_{t}^{N}=\frac{\omega}{1-\omega}\left(c_{t}^{T} / y_{t}^{N}\right)^{1+\eta}$ & $p_{t}^{N}=\frac{\omega}{1-\omega}\left(c_{t}^{T} / y_{t}^{N}\right)^{1+\eta}$ \\
$\lambda_{t}=\beta(1+r) E_{t}\left[\lambda_{t+1}\right]+\mu_{t}$ & $\lambda_{t}^{s p}=\beta(1+r) E_{t}\left[\lambda_{t+1}^{s p}\right]+\mu_{t}^{s p}$ \\
$c_{t}^{T}=y_{t}^{T}+b_{t+1}-(1+r) b_{t}$ & $c_{t}^{T}=y_{t}^{T}+b_{t+1}^{s p}-(1+r) b_{t}^{s p}$ \\
$b_{t+1} \leq \kappa\left(p_{t}^{N} y_{t}^{N}+y_{t}^{T}\right)$ & $b_{t+1}^{s p} \leq \kappa\left(p_{t}^{N} y_{t}^{N}+y_{t}^{T}\right)$
\end{tabular}

Note: The left column describes decentralized equilibrium conditions and the right column contains the social planner's optimality conditions. The equilibrium conditions in this table are taken from Bianchi (2011). $M U_{t}$ is the marginal utility of consumption. $\Phi_{t}=\kappa p_{t}^{N} c_{t}^{N} /\left((1+\eta) c_{t}^{T}\right)$.

consumption good at period 1. In this case, the social planner can choose the optimal level of tradable consumption good by considering the impact of the planner's consumption decision on the credit constraint, whereas individual households cannot do this.

Table 3 compares equilibrium conditions of a decentralized economy with optimality conditions of its corresponding planner's problem. The left column describes decentralized equilibrium conditions and the right column contains the social planner's optimality conditions. The main difference shows up in the first lines of the two columns. The shadow value of households' wealth in the social planner's problem is affected by the Lagrange multiplier of the collateral constraint of households in order to internalize pecuniary externalities.

Following Bianchi (2011), constrained efficient allocations (obtained by the social planner's planning problem) can be attained by imposing tax on issuance of short-term debt. By setting equilibrium conditions under the tax on debt equal to the optimality conditions of the planning problem, the optimal tax rate is given by

$$
1+\tau_{t}^{*}=\frac{E_{t}\left[\mu_{t+1}^{s p} \Psi_{t+1}\right]}{E_{t}\left[M U_{t+1}\right]}-\frac{\mu_{t}^{s p} \Psi_{t}}{\beta(1+r) E_{t}\left[M U_{t+1}\right]}
$$

where $\tau_{t}^{*}$ represents the optimal tax rate on the issuance of short-term debt.

Bianchi, Boz and Mendoza (2012) present a learning channel (for financial innovations) through which pecuniary externalities can take place when households are subject to credit constraints. The specification of their credit constraint can be written as

$$
b_{t+1} / R_{t} \leq \kappa_{t} q_{t} k_{t+1}
$$


where $q_{t}$ is the real price of land (denoted by $k_{t+1}$ ), $R_{t}$ is the gross interest rate, $b_{t+1}$ is the asset holdings of households, and $\kappa_{t}$ reflects financial innovations. In their model, $\kappa_{t}$ varies over time because of financial innovations and pecuniary externalities take place by interactions of the credit constraint with agents' learning about the riskiness of a new financial regime. In their learning scenario, financial innovations create agents's optimistic beliefs that the current financial environment is stable and thus risky assets are not very risky. As a result, they borrow more and bid up the price of risky assets more than in a full-information rational expectations equilibrium. In this framework, the desirability of macro-prudential policy action is associated with pecuniary externalities that arise because individual agents fail to internalize the effect of their borrowing decisions on asset prices.

The coordination between conventional fiscal and monetary policy tools and macroprudential policy measures is an important research topic in this field. In this regards, the recent argument of Benigno, Chen, Otrok, Rebucci, and Young (2012) is worthy of discussion. The first point of their paper is that a credible commitment to support the exchange rate in crisis times always welfaredominates prudential capital controls as it can achieve the first best unconstrained allocations. The second one is that prudential capital controls ar optimal only when the set of policy tools are restricted so that they are the only policy instrument available.

In addition, Yun (2012) analyzes a variant of the prototypical specification of collateral constraints discussed above, in order to show that conventional fiscal and monetary policy measures can have significant impact on the degree of pecuniary externalities. By making distinction between imperfect substitutability between home and foreign goods, we allow for the possibility that a change in the real exchange rate has a significant effect on the collateral constraint of an individual household. Specifically, the credit constraint (in the form of debt-to-GDP ratio) can be written as follows:

$$
E_{t}\left[\epsilon_{t+1}\right] b_{t+1} \leq \kappa\left(p_{t}^{N} y_{t}^{N}+y_{t}^{T}\right)
$$

In addition, the real exchange rate (denoted by $\epsilon_{t}$ ) is defined as follows:

$$
\epsilon_{t}=e_{t}\left(P_{t}^{T}\right)^{*} / P_{t}^{T}
$$

where $e_{t}$ is the nominal exchange rate, $\left(P_{t}^{T}\right)^{*}$ is the nominal price level of foreign country's tradable goods, and $P_{t}$ is the nominal price level of home country's tradable goods. The credit constraint shown above implies that when the value of collateral is deflated by the expected value of nextperiods' real exchange rate, there is a room for conventional fiscal and monetary policy measures to influence the size of pecuniary externalities, to the extent which conventional fiscal and monetary policy measures affect the anticipated real exchange rate. 


\section{Models of Sovereign Debt}

The fundamental issue for sovereign debt is to find a plausible mechanism that leads countries to pay their international debts in the absence of enforceability. As discussed in Uribe (2012), the two main reasons why countries are willing to pay their international debts are economic sanctions and reputation. In particular, the reputation mechanism works because default countries are excluded from international financial markets. In this case, since residents in default countries cannot use the current account to smooth out their consumption, they may want to repay their debts in order to preserve their reputation and thereby maintain access to international financial markets.

We discuss recent sovereign-debt models such as Arellano (2008), Mendoza and Yue (2011) and Kim and Zhang (2011) that build on the sovereign debt model of Eton and Gersovitz (1981). Our starting point is Arellano's model whose basic structure can be summarized as follows:

- The preferences of households at period 0 are represented by $E_{0}\left[\sum_{t=0}^{\infty} \beta^{t} u\left(c_{t}\right)\right]$ where $0<\beta$ $<1$ is the time discount factor and $c_{t}$ is the consumption at period $t$.

- The government trades bonds with risk neutral competitive foreign creditors.

- Debt contracts are not enforceable and the government can choose to default on its debt at any time. As a result, the resource constraint for the small open economy is $c=y+B$ $q\left(B^{\prime}, y\right) B^{\prime}$ when the government chooses to repay its debt and consumption equals output: $c$ $=y^{\text {def }}$ when the government chooses to default.

- If the government defaults, it is assumed to be temporarily excluded from international intertemporal trading and to incur direct output costs.

- Foreign creditors have access to an international credit market in which they can borrow or lend as much as needed at a constant international rate $r>0$. In each period, lenders choose loans $B^{\prime}$ to maximize expected profits $\phi$, taking prices given: $\phi=q B^{\prime}-(1-d) B^{\prime} /(1+r)$, where $d$ is the probability of default.

- The price of each bond available to the government reflects the likelihood of default events. Specifically, the equilibrium price accounts for the risk of default: $q=(1-d) /(1+r)$ for negative holdings $\left(B^{\prime}<0\right)$ and $q=1 /(1+r)$ for positive levels of foreign asset holdings $\left(B^{\prime} \geq 0\right)$ because the probability of default is zero.

By using value functions of households, we can formulate government's decision on default as follows. To the extent which the government chooses to repay its debt, the value function of 
households can be written as

$$
v^{o}(B, y)=\max _{B^{\prime}}\left\{u\left(y-q\left(B^{\prime}, y\right) B^{\prime}+B\right)+\beta \int_{y^{\prime}} v^{o}\left(B^{\prime}, y^{\prime}\right) f\left(y^{\prime}, y\right) d y^{\prime}\right\}
$$

where $v^{o}(B, y)$ represents the value function for the government that does not choose to default and the value function of households under default is

$$
v^{d}(y)=u\left(y^{d e f}\right)+\beta \int_{y^{\prime}}\left(\theta v^{o}\left(0, y^{\prime}\right)+(1-\theta) v^{d}\left(y^{\prime}\right)\right) f\left(y^{\prime}, y\right) d y^{\prime} .
$$

An important implication of this model is the presence of an endogenous "Laffer Curve" for sovereign government debt. For example, when $B^{*}$ represents the maximum level of borrowing from foreign creditors, borrowers would never choose optimally a bond contract with $B<B^{*}$ because they can find an alternative contract that increases consumption today by the same amount while incurring a smaller liability for next period. For the region $B^{\prime} \in\left(B^{*}, \bar{B}\right)$ to be non-empty, the bond price function needs to decrease slowly enough such that lower asset levels are associated with larger capital inflows.

$$
\frac{\partial\left(q\left(B^{\prime}\right) B^{\prime}\right)}{\partial B^{\prime}}=q\left(B^{\prime}\right)\left(1+\epsilon_{q}\right)
$$

where $\epsilon_{q}=q^{\prime}\left(B^{\prime}\right) B^{\prime} / q\left(B^{\prime}\right)$.

The main difference of Kim and Zhang (2011) from Allerano's model is that private agents decide how much to borrow and the government decides whether to default. The empirical motivation behind this assumption is the observation that private firms and individuals in developing countries borrow substantially from foreign lenders. As a result, decentralized borrowing generates overborrowing incentives of private agents because they fail to internalize the impact of their individual borrowing on aggregate borrowing costs. In equilibrium, decentralized borrowing increases aggregate credit costs and sovereign default risk, and reduces aggregate welfare, relative to centralized borrowing.

In the model of Mendoza and Yue (2012), default causes an endogenous efficiency loss in production and bears an endogenous output cost. First, their model links default with private economic activity via the financing cost of working capital used to pay for a subset of imported inputs, while domestic and imported inputs are imperfect substitutes. Second, the output cost of default is an increasing and convex function of the total factor productivity in the final-goods sector. The reason for this result is that the output cost is higher and becomes a steeper function of the total factor productivity at lower elasticities of substitution across inputs that makes production inputs become less similar. The structure of the working capital constraint employed in Mendoza and Yue can be described as follows: 
- Firms in the final goods sector produce their outputs using labor and intermediate goods and a time-invariant capital goods $(=k)$. The production function is Cobb-Douglas:

$$
Y_{F, t}=A_{t} k^{\alpha_{k}} M_{t}^{\alpha_{M}}\left(L_{t}^{f}\right)^{\alpha_{f}}
$$

where $A_{t}$ denotes the aggregate productivity shock at period $t, 0<\alpha_{L}, \alpha_{M}, \alpha_{k}<1$ and $\alpha_{L}+\alpha_{M}+\alpha_{k}=1$. The mix of intermediate goods is determined by a standard CES Arminton aggregator that combines domestic inputs $\left(=m_{t}^{d}\right)$ and imported inputs $\left(=m_{t}^{*}\right)$.

$$
M_{t}=\left(\lambda\left(m_{t}^{d}\right)^{\mu}+(1-\lambda)\left(m_{t}^{*}\right)^{\mu}\right)^{\frac{1}{\mu}} .
$$

- Each firm's purchases of variety of imported inputs are denoted by $m_{j t}^{*}$. The CES aggregator of imported inputs is given by $m_{t}^{*}=\int_{i=0}^{1}\left(\left(m_{i t}^{*}\right)^{\nu} d i\right)^{1 / \nu}$ where the "within" elasticity of substitution across all varieties is given by $|1 /(\nu-1)|$. Imported inputs are sold in the world markets at exogenous time-invariant prices $p_{j t}^{*}$ for $j \in\left[\begin{array}{ll}0 & 1\end{array}\right]$

- A subset $\Omega$ of the imported input varieties defined by the interval $\left[\begin{array}{ll}0 & \theta\end{array}\right]$, for $0<\theta<1$, needs to be paid in advance using working capital financing. Pay-in-advance constraint condition for a subset of imported intermediate goods:

$$
\frac{\kappa_{t}}{1+r_{t}^{*}} \geq \int_{0}^{\theta} p_{j, t}^{*} m_{j, t}^{*} d j
$$

- Working capital loans $\kappa_{t}$ are within-period loans provided by foreign creditors. These loans are contracted and repaid after the uncertainty about the government's repayment of its current debt service resolved. Under this assumption, working capital loans are contracted at the risk-free world real interest rate denoted by $r_{t}^{*}$. If government repays, firms borrow at $r_{t}^{*}$ and if it does not, they are excluded from world credit markets.

Bianchi, Hatchondo and Martinez (2012) show that the introduction of long-term debt into the framework of Eton and Gersovitz is crucial to explain the simultaneous accumulation of sovereign debt and foreign reserves. The target empirical regularities of their paper can be summarized as follows.

- Non-resident purchases of domestic assets (the increase in the government's debt level) are procyclical.

- Purchases of foreign assets by domestic agents (increases in reserves) are procyclical.

- Changes in reserves represent about half of purchases of foreign assets by domestic agents and contract significantly during crisis episodes. 
The key point of their modeling strategy is that although we typically have a negative correlation between the amount of foreign reserves and government debt in the case of one-period debt alone, the presence of long-term debt helps obtain a positive correlation between the amount of foreign reserves and government debt.

An important feature of their model is that the long-term bond in their model is a real consol. Specifically, this long-term bond issued at period $t$ promises to pay one unit of consumption good at period $t+1$ and $(1-\delta)^{j-1}$ units at period $t+j$ for $j \geq 2$. The total amount of coupons from outstanding long-term bonds has a recursive structure:

$$
b_{t}=(1-\delta) b_{t-1}+z_{t}
$$

where $b_{t}$ is the number of coupons due at the beginning of period $t$ and $z_{t}$ is the number of bonds issued in period $t$. The government's decision on default in their model can be formulated as follows. To the extent which the government chooses to repay its debt, the value function of households can be written as

$$
v^{o}(b, a, y, s)=\max _{b^{\prime}, c, a^{\prime}}\left\{u(c)+\beta E\left[v^{o}\left(b^{\prime}, a^{\prime}, y^{\prime}, s^{\prime}\right)\right]\right\}
$$

where $v^{o}(b, a, y, s)$ represents the value function for the government that does not choose to default and the value function of households under default is

$$
v^{d}(a, y, s)=\max _{c, a^{\prime}}\left\{u(c)+\beta\left(\theta E\left[v^{o}\left(0, a^{\prime}, y^{\prime}, s^{\prime}\right)\right]+(1-\theta) E\left[v^{d}\left(a^{\prime}, y^{\prime}, s^{\prime}\right)\right]\right)\right\}
$$

In their model, the sudden stop shock is denoted by $s$, so that $s=1$ indicates that the economy is in a sudden-stop. In addition, the price of long-term bond is determined as follows:

$$
q_{t}(1+r)=E_{t}\left[\left(1-d_{t+1}\right)\left(1+(1-\delta) q_{t+1}\right)\right]
$$

where $q_{t}$ is the price at period $t$ of the long-term bond and $d_{t+1}$ is the probability of default at period $t+1$.

The main reason why we have a positive correlation between foreign reserves and government debt in the presence of long-term government debt can be written as follows. An increase in the amount of foreign reserves raises the probability of default in the next period because the accumulation of foreign reserves lowers the potential cost that is incurred from the removal of access to the international capital market. The price of long-term bonds is less sensitive to increases in the probability of default in the next period than that of one-period bond. Hence, the accumulation of foreign reserves becomes cheaper when government can issue long-term bonds.

We now modify a prototypical model of sovereign debt to show the negative correlation between the maturity of foreign debt and the accumulation of foreign reserves when the level of foreign debt 
is substantially high. In our modification, the maturity of long-term debt is increasing in the size of long-term debt:

$$
\delta=\left\{\begin{array}{cl}
\delta & \text { if } b^{\prime}<\bar{b} \\
\phi\left(b^{\prime}\right) & \text { if } \bar{b} \leq b^{\prime} \leq b^{*}
\end{array}\right.
$$

where function $\phi(x)$ is increasing in $x$.

Our motivation behind this modification is associated with the empirical relation between the size of the public debt and the maturity structure of government securities exhibits a non-linear relation. For example, Missale and Blanchard (1994) found a strong inverse relation between maturity and the debt-to-GDP ratio for countries which reached debt-to-GDP ratios approaching or exceeding 100 percent. An explanation about this observation is that high inflation is associated with higher inflation uncertainty, leading to higher risk premium on long-term nominal debt and thus governments to stop issuing long-term debt. ${ }^{3}$

\section{Development of Macroeconomic Policy Models}

In this section, we turn to impacts of conventional and unconventional monetary policy measures in emerging-market economies. In particular, this discussion is included because both advanced and emerging economies were hit hard by the recent global financial crisis.

We begin with the limitation of conventional measures in emerging-market economies by emphasizing that the effectiveness of lowering the short-term nominal interest rate is more non-linear in emerging-market economies than in advanced countries. First, the real expected interest rate becomes negative at levels of the short-term nominal interest rate that are not sufficiently low, considering that the expected inflation rate is high in emerging market economies. Second, financial market participants might respond sensitively to the possibility of future drops of the policy rate. Third, there is lack of deep markets in government and private-sector securities.

The recent practice of monetary policy in emerging economies can be summarized as follows. First, emerging-market economies utilized unconventional and then conventional measures during the recent financial crisis. Second, emerging-market economies performed unconventional measures only in September 2008 in response to the sudden tightening of global liquidity when foreign exchange liquidity available in local markets quickly dried up as stress in global dollar markets heightened.

\footnotetext{
${ }^{3}$ The explanation explored by Missale and Blanchard is that the government would choose a shorter maturity in order to make its non-inflation pledge especially when the government might have a strong incentive to inflate away its nominal debt. Yun (2011) also discusses the possibility that since the risk aversion of investors for government securities is associated with the level of the public debt relative to GDP, a higher debt-to-GDP ratio leads to a higher risk premium on long-term nominal debt and thus the government eventually stops issuing its long-term bonds with an extremely large amount of the public debt.
} 
Table 4: Exchange Rate Movements during Normal and Crisis Times in Emerging Economies Volatility

$\begin{array}{lccccc} & \text { Normal } & \text { Crisis } & \text { 2008 Lehman } & \text { 2010 Greece } & \text { 2011 Euro } \\ \text { Average } & 9.4 & 16.8 & 18.8 & 15.0 & 13.5 \\ \text { Top-25 \% } & 12.3 & 24.1 & 25 & 18.1 & 18.2 \\ \text { Bottom-25\% } & 5.7 & 9.1 & 8.8 & 9.8 & 8.8\end{array}$

Sharp Depreciation

$\begin{array}{lccc} & \text { 2008 Lehman } & \text { 2010 Greece } & \text { 2011 Euro } \\ \text { Average } & 22.5 & 4.2 & 10.5 \\ \text { Top-25\% } & 34.7 & 5.3 & 15.4 \\ \text { Bottom-25\% } & 9.1 & 2.7 & 6.7\end{array}$

Note: The numbers reported in this table are taken from Kim (2012).

In particular, we note that emerging-market countries adopted unconventional measures in the first place and then used conventional measures. The reason why they did so is that emerging market economies were grappling with capital inflow and inflationary pressures before September 2008. Given this environment, they initiated unconventional measures only in September 2008 in order to cope with the sudden tightening of global liquidity. The policy interest rates were reduced in many economies beginning only in November 2008.

Another difference lies in the relative use of credit and quantitative easing measures: several advanced economy central banks relied heavily on these measures, whereas they were barely used by emerging economy central banks. Early in 2009, after policy interest rates dwindled to near zero, the Federal Reserve and Bank of England made large purchases of government securities, and the Federal Reserve also effectively provided credit of a large magnitude via several new facilities. On the contrary, no emerging economy central banks, except Israel for a relatively brief period (March to August, 2009) implemented quantitative easing measures, and only a few emerging economy central banks seemed to have introduced what can be viewed as credit easing measures.

Many of emerging-countries central banks have employed unconventional measures to help alleviate liquidity stresses in foreign exchange and domestic financial markets in the relatively short run and with some apparent success. Hence, both advanced and emerging economies adopted a variety of liquidity-easing measures but differ in some aspects. First, the scale of liquidity-easing measure in emerging economies is small, relative to that of advanced economies. Second, advanced economies undertook securities liquidity provision, while apparently no emerging economy central 
banks did so. Third, both advanced and emerging-market central banks employed foreign-exchange liquidity-easing measures. Central banks from both groups of economies undertook liquidity swap arrangements with the Fed and ECB.

Table 4 shows relatively high volatilities and sharp depreciations of exchange rates in emergingmarket countries. First, the volatility of nominal exchange rate in crisis becomes as twice as that of normal times. Second, this table indicates that the bankruptcy of Lehman Brothers (in September 2008) created the largest shock to foreign-exchange markets in emerging economies, recording 22.5 percent depreciation (on average) of emerging-economies currencies after the bankruptcy of Lehman Brothers. Third, in actual data, there are extended periods of slow appreciations of the high rate currency that stochastically end with currency crashes. Currency traders refer to such extreme patterns as "going up in the elevator and coming down by the stairs". 4 Such a behavior of the nominal exchange rate was apparent in foreign-exchange markets of emerging-economies during the recent global financial crisis.

We now use a simplified version of the New Keynesian small open-economy model such as Gali and Monacelli (2005) in order to explain the observed behavior of exchange rate movements (summarized in Table 4). Although our discussion relies on a very simple specification of the model, we expect that our result can still hold in a full-blown model. In particular, we are focused on the behavior of nominal exchange rate during the recent financial crisis when emerging countries fixed their policy rates at low levels.

Our model consists of three equations: The uncovered parity equation augmented by the inclusion of the central bank's holdings of foreign assets, the relation between country premium and foreign reserves, and the interest rate rule. Specifically, the uncovered interest parity condition for small open economies is

$$
i_{t}=i_{t}^{*}+E_{t}\left[e_{t+1}\right]-e_{t}+c p_{t}+\phi_{s} \Delta b_{t}^{*}
$$

where $i_{t}$ is the policy rate of home country, $i_{t}^{*}$ is the policy rate of foreign country, $e_{t}$ is the nominal exchange rate, $c p_{t}$ is the country premium at period $t$, and $\Delta b_{t}^{*}$ represents the logarithmic change in the central bank's holdings of foreign assets. In addition, the country premium is negatively related to the level of foreign assets held by the central bank:

$$
c p_{t}=-\phi_{c} b_{t}^{*}+v_{t}
$$

\footnotetext{
${ }^{4}$ In the literature, it has been emphasized that dramatic exchange rate movements can take place without having fundamental news announcements: The large depreciation of the US Dollar against the Japanese Yen took place on October 7th and 8th of 1998. Sudden exchange-rate changes that are not associated with news can arise because of the unwinding of carry trades when speculators are near funding constraints. The currency carry trade takes place by selling low interest-rate currencies (i.e. funding currencies) and purchasing high interest-rate currencies (i.e. investment currencies).
} 
where $v_{t}$ is the exogenous shock to the country premium and $\phi_{c}$ is a positive constant. The interest rate rule of the central bank is given by

$$
i_{t}=\rho i_{t-1}+(1-\rho)\left(\phi_{\pi} \pi_{t}+\phi_{y} y_{t}\right)
$$

where $\rho$ is a positive constant $(<1), \pi_{t}$ is the inflation rate, and $y_{t}$ is the log deviation of the real output at period $t .^{5}$

We now assume that the central banks of advanced countries ran into setting their policy rates at their zero lower bounds. The central bank of home country sets its policy rate at a positive level denoted by $d$. As a result, we set $i_{t}^{*}=0$ and $i_{t}=d$. In this case, the substitution of the country premium equation into the uncovered interest parity condition leads to the following equation:

$$
d+e_{t}=E_{t}\left[e_{t+1}\right]+v_{t}+\phi_{s} \Delta b_{t}^{*}-\phi_{c} b_{t}^{*}
$$

Next, we discuss impacts of two different exchange-rate policy regimes. The first one is a fixed exchange-rate regime. To the extent which agents believe that the exchange rate can be fixed in current and future periods, we can set $e_{t}=E_{t}\left[e_{t+1}\right]=\bar{e}$. In this case, the uncovered interest parity condition becomes

$$
d=v_{t}+\phi_{s} \Delta b_{t}^{*}-\phi_{c} b_{t}^{*}
$$

Hence, in order to achieve the exchange-rate stability, the required level of foreign reserves is proportional to the expected discounted sum of (net of policy interest differential) future exogenous shocks to the country premium:

$$
b_{t}^{*}=\phi_{s}^{-1} \sum_{k=1}^{\infty} \phi^{k-1} E_{t}\left[v_{t+k}-d\right] \quad \phi=\frac{\phi_{s}-\phi_{c}}{\phi_{s}} \quad|\phi|<1
$$

The second one is a nominal exchange-rate targeting regime in which the expected change in the nominal exchange rate offsets the current exogenous shock to the country premium:

$$
E_{t}\left[e_{t+1}\right]=e_{t}-v_{t}
$$

In this case, the nominal exchange rate responds to current and future expected exogenous shocks to the country premium:

$$
e_{t}=\sum_{k=0}^{\infty} E_{t}\left[v_{t+k}\right]
$$

The substitution of the country premium equation into the uncovered interest parity condition then leads to the following equation:

$$
d=\phi_{s} \Delta b_{t}^{*}-\phi_{c} b_{t}^{*}
$$

\footnotetext{
${ }^{5}$ Javier Garcia-Cicco (2011) presents a modified version of the prototypical New Keynesian small-open economy model for emerging-market economies and use it to analyze the impact of unconventional monetary policy measures.
} 
In particular, this exchange-rate targeting regime is still effective even when the current level of foreign reserves falls short of its long-run average. For example, if we set the policy rate of home country at $d=-(1-\phi) \phi_{s} b_{-1}^{*}$ and $b_{-1}^{*}<0$, the required level of foreign reserves to maintain this exchange-rate targeting is

$$
b_{t}^{*}=-\frac{d}{(1-\phi) \phi_{s}} .
$$

The negative value of the initial foreign reserves means that the initial value of foreign reserves is less than the steady-state level of foreign reserves. Hence, this exchange-rate targeting regime can be maintained with a low level of foreign reserves.

A practical implication of this exchange-rate targeting is that it can help explain the observed behavior of the nominal exchange rate in emerging economies during the recent financial crisis. In other words, this model can help explain the reason why there are sharp depreciations of their nominal exchange rates followed by extended periods of slow appreciations, especially when both advanced and emerging countries fix their policy rates. 


\section{References}

Aguiar, M. and Gopinath, G. 2006. "Defaultable Debt, Interest Rates and the Current Account." Journal of International Economics. Vol. 69. pp. 64-83.

Aguiar, M. and Gopinath, G. 2007. "Emerging Markets Business Cycles: The Cycle Is the Trend." Journal of Political Economy. Vol. 115 (1). pp. 69-102.

Arellano, C. 2008. "Default Risk and Income Fluctuations in Emerging Economies." American Economic Review. Vol. 98 (3). pp. 690-712.

Benigno G., Chen H., Otrok C., Rebucci A., and Young E. 2012. "Capital Controls or Exchange Rate Policy? A Pecuniary Externality Perspective." Federal Reserve Bank of St. Louis Working Paper Series 2012-025A. July.

Bianchi, J. 2011 "Overborrowing and Systemic Externalities in the Business Cycle." American Economic Review. Vol. 101(7). pp. 3400-3426.

Bianchi, J. Hatchondo Juan Carlos, and Leonardo Martinez. 2012. "International Reserves and Rollover Risk." Unpublished Manuscript. Indiana University. April.

Bianchi J. Boz E. and E. Mendoza. 2012. "Macro-Prudential Policy in a Fisherian model of Financial Innovation." NBER Working Papers No. 18036. NBER.

Blanchard, O. and Alessandro M. 1994. "The Debt Burden and Debt Maturity." American Economic Review. Vol. 84 (1). pp. 309-319.

Durdu B. 2012. "Emerging Market Business Cycles: Recent Advances." Unpublished Manuscript. Federal Reserve Board.

Eaton, J. and Gersovitz, M. 1981. "Debt with Potential Repudiation: Theoretical and Empirical Analysis." Review of Economic Studies. Vol. 48. pp. 289-309.

Frankel J. 2011. "Monetary Policy in Emerging Market." Handbook of Monetary Economics. Vol. 3. Chapter 25.

Gali J. and Monacelli T. 2005. "Monetary Policy and Exchange Rate Volatility in a Small Open Economy." Review of Economic Studies. Vol. 72 (3), pp. 707-734.

Javier G. 2011. "On the Quantitative Effects of Unconventional Monetary Policies in Small Open Economies." International Journal of Central Banking. March. pp. 53-115.

Javier G., Pancrazi R. and M. Uribe. 2010. "Real Business Cycles in Emerging Countries?" American Economic Review. Vol. 100. pp. 2510-2531.

Kim Y. J. and J. Zhang. 2011. "Decentralized Borrowing and Centralized Default." Unpublished Manuscript. University of Michigan. December.

Korineck A. 2011. "The New Economics of Prudential Capital Controls: A Research Agenda." IMF Economic Review. Vol. 59 (3). pp. 523-561.

Mendoza, E. and Yue, V. 2012. "A General Equilibrium Model of Sovereign Default and Business Cycles". The Quarterly Journal of Economics. Vol. 127(2). pp. 889-946. 
Mendoza, E. 1991. "Real Business Cycles in a Small Open Economy." American Economic Review. Vol. 81 (4). pp. 797-818.

Uribe M. and Yue, V. 2006. "Country Spreads and Emerging Countries: Who Drives Whom?" Journal of International Economics. Vol. 69. pp. 6-36.

Uribe M. 2012. "Open Economy Macroeconomics." Unpublished Manuscript. Columbia University. August.

Yun T. 2012. "Fiscal Risks and Macroprudential Policy in Emerging-Market Economies." Unpublished Manuscript. Seoul National University. August.

Yun T. 2011. "Transmission Mechanisms of the Public Debt." Unpublished Manuscript. Seoul National University. November. 